\title{
The life and works of Johannes Schultheiss (1595-1645), who was the pioneer surgeon
}

\author{
Illhan Bahşi ${ }^{1}$ (D) Saliha Seda Adanır ${ }^{1}$ \\ Received: 21 February 2019 / Accepted: 27 February 2019 / Published online: 8 March 2019 \\ (C) Springer-Verlag GmbH Germany, part of Springer Nature 2019
}

\section{His life}

Johannes Schultheiss (German as Johann Schulte, Latinized as Johannes Scultetus) was born on October 12,1595, in Ulm, Germany. When he was 13 years old, both his father and mother died. He worked in various jobs at young age due to financial difficulties. While he was working in Vienna, he met Adriaan van de Spieghel, a Belgian physician. Spieghel was interested by this intelligent, young man and took him as his servant on his trip to Padua. Adriaan van de Spieghel discovered the talents within him. Soon after, Schultheiss was a successful student instead of the servant [1]. In 1621, he continued his studies at the University of Padua, Italy, where he received his MD degree from that institution at the age of twenty-six [2]. After studying at the University of Padua, where he received his $\mathrm{PhD}$ in medicine and surgery, he became a famous city doctor in Ulm, Germany. Schultheiss died due to apoplexia in 1645 at the age of 50 years [3].

Johannes Schultheiss, as well as his very good medical education, also took care of Spieghel's patients. Schultheiss became "prosector anatomicus" of Spieghel and had the opportunity to learn more about human anatomy than other students. It is estimated that he dissected hundreds of human cadaver [1].

For his outstanding achievements, Johannes Schultheiss (1595-1645) is considered one of the best surgeons of the seventeenth century. He is remembered in particular for the

İlhan Bahși

dr.ilhanbahsi@gmail.com

Saliha Seda Adanır

seda.adnr93@gmail.com

1 Department of Anatomy, Faculty of Medicine, Gaziantep University, TR-27310 Gaziantep, Turkey large number of bandages that he introduced to surgery, each being adapted to its specific purpose [2].

\section{Armamentarium Chirurgicum}

He wrote the book that is named Armamentarium Chirurgicum, one of the first surgical books in Latin (Fig. 1). This book was soon translated into German, English, and French [1]. The wide historic impact on the development of modern medicine at the seventeenth and eighteenth century can be measured by the fact that 18 editions were published until 1748 [3]. In this book, he referred to many scientists who came before him, famous historic and contemporary physicians [1]. Also innovations and complex devices developed or modified by Schultheiss were shown in this book (Fig. 2) [2]. In addition, surgical techniques used to reduce fractures and dislocations, amputation of limbs, breasts, and other surgical procedures, the surgical treatment of skull fractures and injuries on the pericranium (Fig. 3 and Cover) are shown. Strohl [2] stated that modern surgery is appreciative to this great German surgeon. Schultheiss and Jonas [3] stated that the works of Schultheiss, especially the achievement and spreading of his textbook Armamentarium Chirurgicum, conduced to the admission of surgery as an academic specialty in Northern Europe.

\section{Conclusion}

In spite of the difficult conditions, his contribution to medicine cannot be underestimated. For these reasons, he should be appreciated.

\section{Compliance with ethical standards}

Conflict of interest The authors declare that there is no conflict of interest. 


\section{ARMAMENTARIVM CHIR VRGICV.M B I P A R T I T V M,}

Studioq́; \& operêz

D. FOANNIS SCULTETI ULMENSIS, Reipubl. Patria Phyfici ordinarÿ, reformatum, correctum \& axclum.

Cum LVI. Tabulis, five. Figuris neis novis accuratiffimis.

\section{v 8}

Tribus Indicibus abfolutißimis, ...

INSTRUMENTORUM SCILICET, OBSERVATIONUM, et Rerta Notabilium.

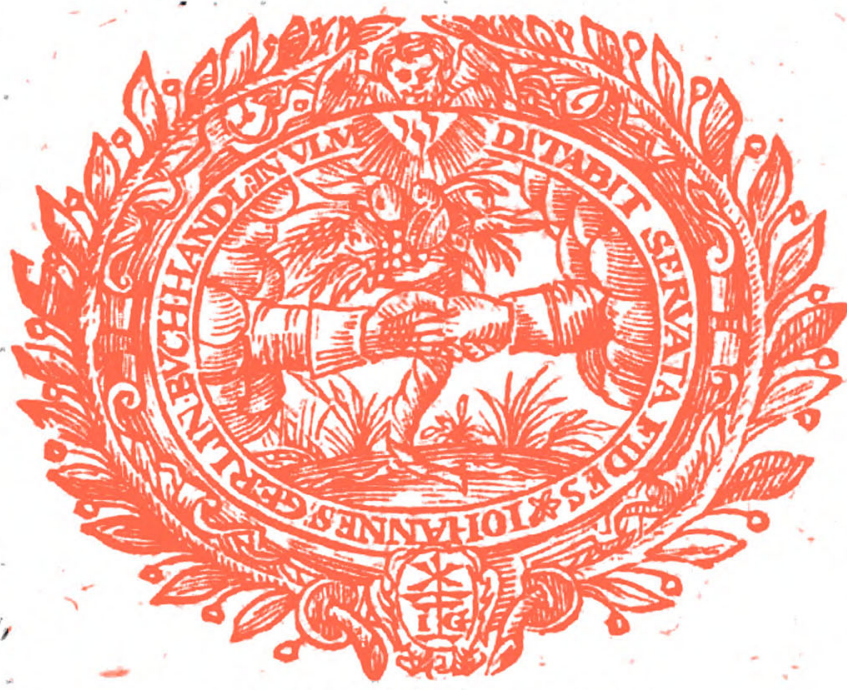

\section{FRAN COFURTT,}

Sumptibus Vidua Joan. Gerini, Bibliop. Ullim.

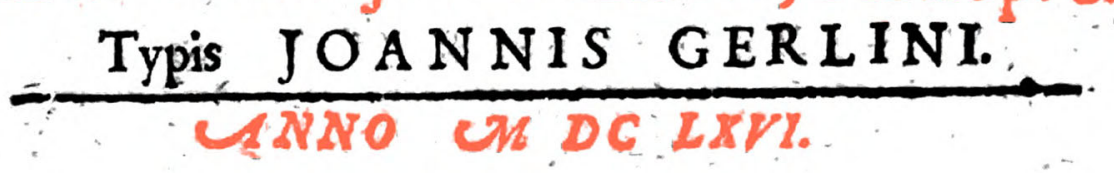

Fig. 1 Title page of Armamentarium Chirurgicum 

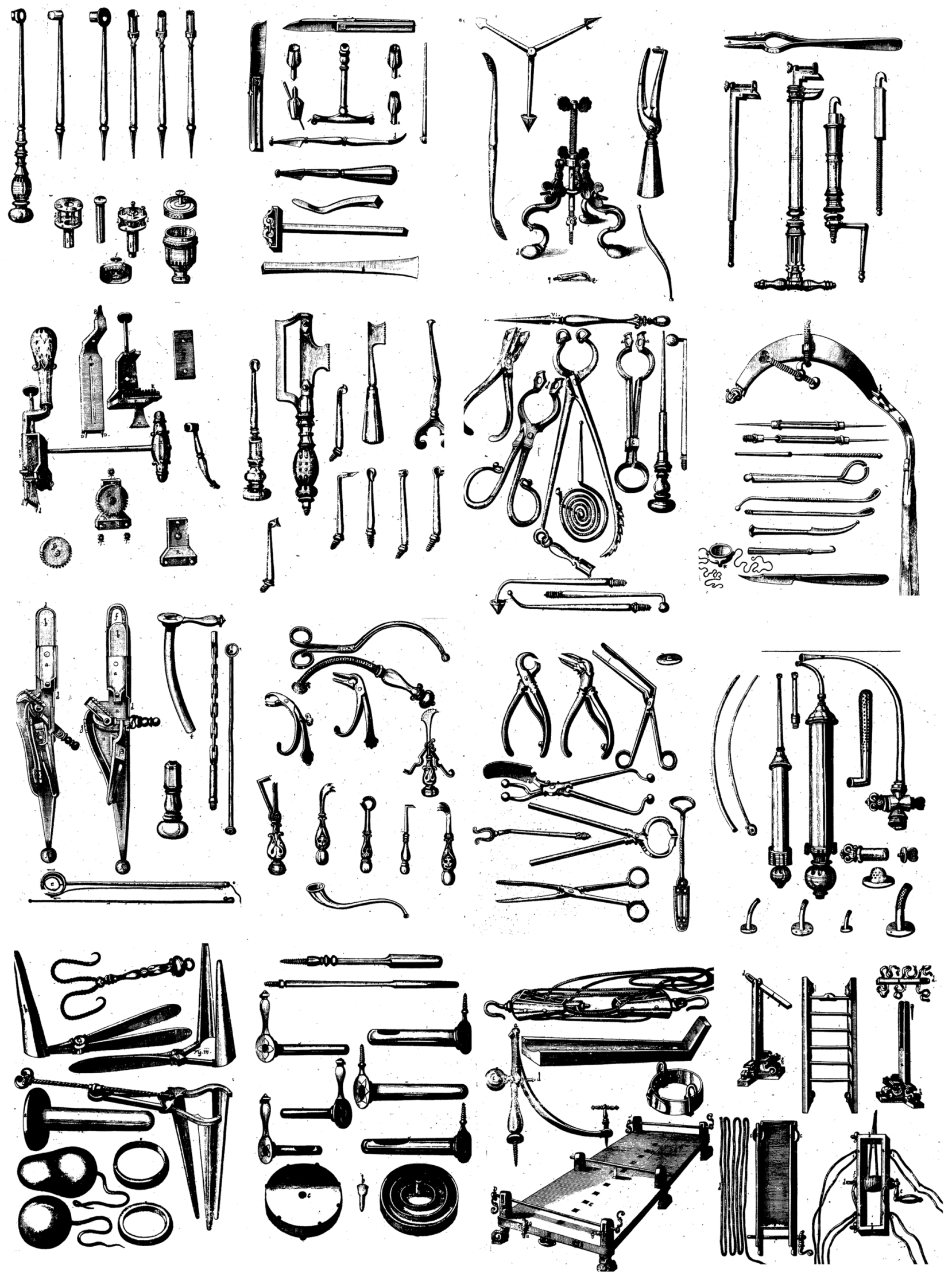

Fig. 2 The illustrations of some surgical instruments in Armamentarium Chirurgicum 


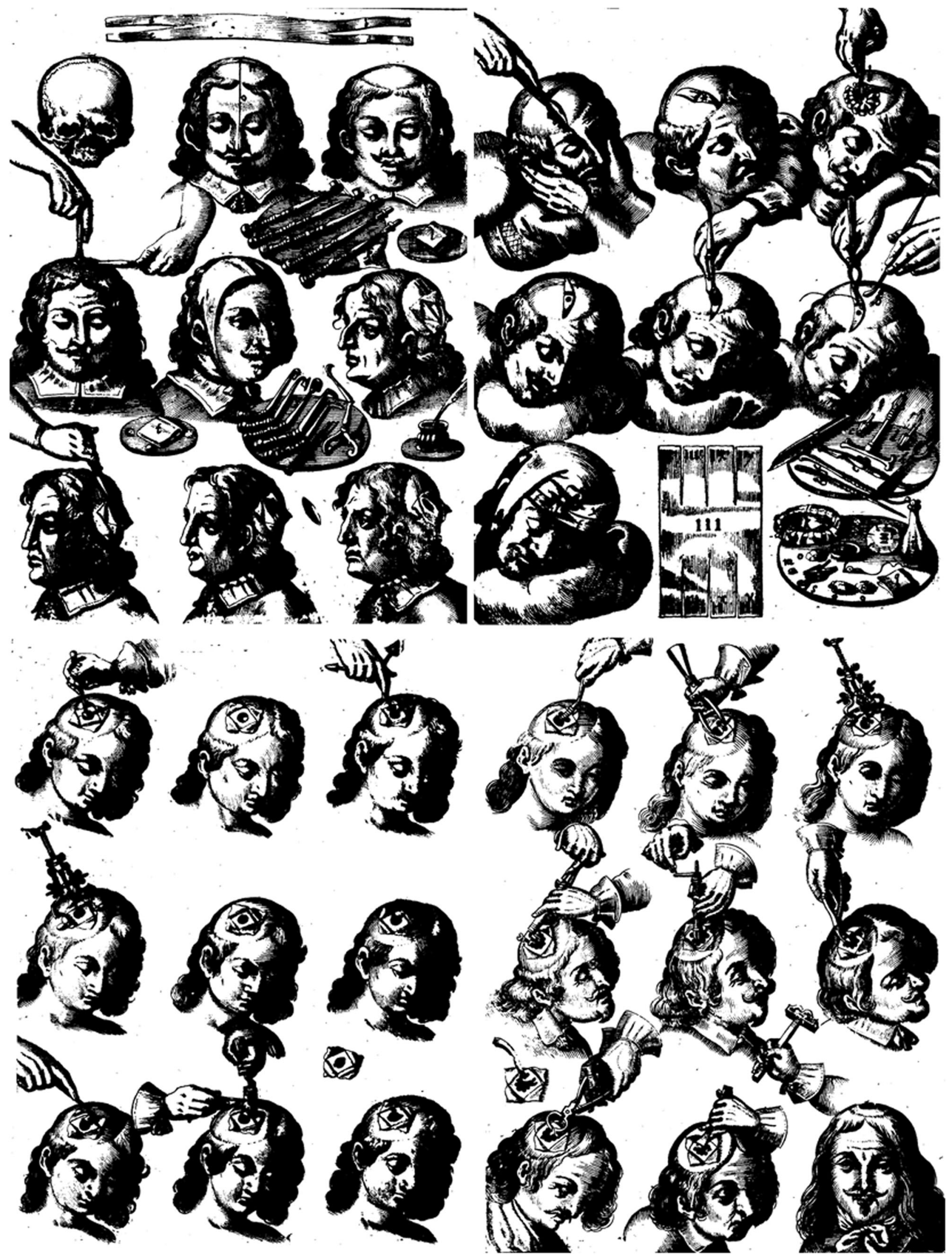

Fig. 3 and Cover Some techniques used to treat skull fractures and pericranium injuries in Armamentarium Chirurgicum 
Publisher's note Springer Nature remains neutral with regard to jurisdictional claims in published maps and institutional affiliations.

\section{References}

1. Scultetus AH, Villavicencio JL, Rich NM (2003) The life and work of the German physician Johannes Scultetus (1595-1645). J Am Coll Surg 196(1):130-139
2. Strohl EL (1963) Johannes Scultetus (1595-1645). Arch Surg 87(3): 396-397

3. Schultheiss D, Jonas U (1998) Johannes Scultetus (1595-1645). Urologic aspects in the 'Armamentarium chirurgicum'. Eur Urol 34(6):520-525 